\title{
HNF1alpha-Inactivated Hepatocellular Adenoma
}

National Cancer Institute

\section{Source}

National Cancer Institute. HNF1alpha-Inactivated Hepatocellular Adenoma. NCI

Thesaurus. Code C96758.

A hepatocellular adenoma caused by inactivating mutations of the HNF1A gene. It is characterized by the presence of lobulated contours, steatosis, and absence of inflammation or nuclear atypia. 